\title{
Risk Assessment of 5-Chloro-2-Methylisothiazol-3(2H)-One/ 2-Methylisothiazol-3(2H)-One (CMIT/MIT) Used as a Preservative in Cosmetics
}

\author{
Min Kook Kim ${ }^{1}$, Kyu-Bong Kim², Joo Young Lee ${ }^{3}$, Seung Jun Kwack ${ }^{4}$, Yong Chan Kwon ${ }^{1}$, \\ Ji Soo Kang ${ }^{1}$, Hyung Sik Kim ${ }^{1}$ and Byung-Mu Lee ${ }^{1}$ \\ ${ }^{1}$ Division of Toxicology, College of Pharmacy, Sungkyunkwan University, Suwon, Korea \\ ${ }^{2}$ College of Pharmacy, Dankook University, Cheonan, Korea \\ ${ }^{3}$ College of Pharmacy, The Catholic University of Korea, Bucheon, Korea \\ ${ }^{4}$ College of Natural Science, Changwon National University, Changwon, Korea
}

\begin{abstract}
The mixture of 5-chloro-2-methylisothiazol-3(2H)-one (CMIT) and 2-methylisothiazol-3(2H)-one (MIT), CMIT/ MIT, is a preservative in cosmetics. CMIT/MIT is a highly effective preservative; however, it is also a commonly known skin sensitizer. Therefore, in the present study, a risk assessment for safety management of CMIT/MIT was conducted on products containing $0.0015 \%$ of CMIT/MIT, which is the maximum MIT level allowed in current products. The no observed adverse effect level (NOAEL) for CMIT/MIT was $2.8 \mathrm{mg} / \mathrm{kg}$ bw/day obtained from a two-generation reproductive toxicity test, and the skin sensitization toxicity standard value for CMIT/MIT, or the no expected sensitization induction level (NESIL), was $1.25 \mu \mathrm{g} / \mathrm{cm}^{2} /$ day in humans. According to a calculation of body exposure to cosmetics use, the systemic exposure dosage (SED) was calculated as $0.00423 \mathrm{mg} / \mathrm{kg} \mathrm{bw} / \mathrm{day}$ when leave-on and rinse-off products were considered. Additionally, the consumer exposure level (CEL) amounted to $0.77512 \mu \mathrm{g} / \mathrm{cm}^{2} /$ day for all representative cosmetics and $0.00584 \mu \mathrm{g} / \mathrm{cm}^{2} /$ day for rinse-off products only. As a result, the non-cancer margin of safety (MOS) was calculated as 633, and CMIT/MIT was determined to be safe when all representative cosmetics were evaluated. In addition, the skin sensitization acceptable exposure level (AEL)/CEL was calculated as 0.00538 for all representative cosmetics and 2.14225 for rinse-off products; thus, CMIT/MIT was considered a skin sensitizer when all representative cosmetics were evaluated. Current regulations indicate that CMIT/MIT can only be used at concentrations $0.0015 \%$ or less and is prohibited from use in other cosmetics products. According to the results of this risk assessment, the CMIT/MIT regulatory values currently used in cosmetics are evaluated as appropriate.
\end{abstract}

Key words: Risk assessment, CMIT/MIT, Preservative, Cosmetics, Skin sensitization, Margin of safety

Correspondence to: Byung-Mu Lee, Division of Toxicology, College of Pharmacy, Sungkyunkwan University, Seobu-ro 2066, Suwon, Gyeonggi-do 16419, Korea

E-mail: bmlee@skku.edu

This is an Open-Access article distributed under the terms of the Creative Commons Attribution Non-Commercial License (http:// creativecommons.org/licenses/by-nc/3.0) which permits unrestricted non-commercial use, distribution, and reproduction in any medium, provided the original work is properly cited.
List of abbreviations: BIT, 1,2-Benzisothiazolin-3-one; CEL, Consumer exposure level; CIR, Cosmetic Ingredient Review; CMEM, Complete minimum essential medium; CMIT, 5-Chloro-2-methylisothiazol-3(2H)-one; EC3, Effective concentration of chemical required to induce in the LLNA, a three-fold increase in lymph node cell proliferation compared with vehicle control values; EU, European Union; HRIPT, Human Repeat Insult Patch Testing; IP, Intraperitoneal; IV, Intravenous; IVS, In vitro score; LD, Lethal dose; LLNA, Local lymph node assay; LOAEL, Lowest observed adverse effect level; MIT, 2-methylisothiazol-3(2H)-one; NOAEL, No observed adverse effect level; NOEL, No observed effect level; RD, Respiratory rate decrease; RIVM, National Institute for Public Health and the Environment; SAF, Sensitisation assessment factors. 


\section{INTRODUCTION}

Isothiazolinone-based compounds, such as 5-chloro-2methylisothiazol-3(2H)-one (CMIT), 2-methylisothiazol$3(2 \mathrm{H})$-one (MIT), and a mixture of CMIT and MIT (CMIT/MIT), are used as preservatives in several industrial products, such as cosmetics, paints, adhesives, and detergents. CMIT/MIT is the product of a chemical reaction between CMIT and MIT. It is sold under several commercial names, such as Kathon CG, Kathon 886, Kathon 886 WT, Acticide LG, Acticide 14L, Acticide 14P, Microcare IT, and Microcare ITL; these differ in proportions of the active ingredients, i.e., CMIT/MIT, salt, and water (1). Among isothiazolinone-based compounds, CMIT/MIT has been commonly used as a preservative since the early 1980 s, owing to its high activity against microbial contaminants at very low concentrations and at a broad $\mathrm{pH}$ range (2-6).

Isothiazolinone-based compounds exert their antimicrobial activity via the reaction of their nitrogen $(\mathrm{N})$-sulfur (S) bonds with the thiol groups in the cell membranes of the target microorganisms (6). The oxidation of thiol groups causes formation of free radicals which can lead to cell death. In addition, these preservatives interfere with the Krebs cycle, which is associated with adenosine triphosphate (ATP) production, consequently inhibiting the microbial growth and metabolism (6).

Before 1989, CMIT/MIT, containing 1.5\% active ingredients and sold under the trade name Kathon CG and, was primarily used as a preservative in cosmetics in a ratio of 3:1 (1). However, the first case of skin sensitization by cosmetics containing CMIT/MIT was reported in 1985 $(7,8)$. Since then, several cases of skin allergy have been reported, identifying CMIT/MIT to be a common skin sensitizer (5,9-11). This resulted in lowering the concentration of CMIT/MIT to $0.0015 \%$ for both rinse-off products, such as shampoos, hair conditioners, shower gels, body wash, liquid soap, and surfactants, and leave-on products in 1989 in Europe (12). Similarly, in 1992, the limit was set to $0.0015 \%$ for rinse-off products and $0.00075 \%$ for leave-on products in the United States (13). Despite lowering the concentration limits of CMIT/MIT, the incidence rate of skin sensitization remained high and steady at 1 to $4 \%(14,15)$. At present, in Korea and Europe, the concentration of CMIT/MIT is limited to $0.0015 \%$ or less for rinse-off products $(16,17)$.

Industrial compounds, including cosmetics, are routinely assessed and screened for their potential risks to ensure they meet the safety standards (18-22). In addition to risk assessment, studies on their toxicological profiles, alternative testing methods, as well as research on safety management and mechanism of action of cosmetic ingredients have been conducted (23-27). In the present study, we assessed the potential risk factors associated with CMIT/ MIT to confirm its appropriateness for use as per the current safety standards for cosmetics. The risk assessment data used in the study included risk assessment guidelines; risk assessment methods; physical and chemical properties; regulatory values; toxicological data, absorption, distribution, metabolism, excretion (ADME) data; and skin absorption rate of CMIT/MIT. The approach used in the present study was based on the data published in the international journals and that recommended by the international cosmetic risk assessment agencies (e.g., Scientific Committee on Consumer Safety [SCCS], Cosmetic Ingredient Review [CIR], etc.). In addition, appropriate toxicity

Table 1. Physicochemical properties of CMIT/MIT

\begin{tabular}{|c|c|c|c|}
\hline Properties & & Contents & \\
\hline $\begin{array}{l}\text { Chemical name } \\
\text { (INCI) }\end{array}$ & Methylchloroisothiazolinone & Methylisothiazolinone & $\begin{array}{l}\text { Methylchloroisothiazolinone/ } \\
\text { methylisothiazolinone }\end{array}$ \\
\hline Abbreviation & CMIT & MIT & CMIT/MIT \\
\hline IUPAC name & $\begin{array}{l}\text { 5-chloro-2- } \\
\text { methylisothiazol-3(2H)-one }\end{array}$ & $\begin{array}{l}\text { 2-Methylisothiazol- } \\
\text { 3(2H)-one }\end{array}$ & - \\
\hline CAS number & $26172-55-4$ & $2682-20-4$ & $55965-84-9$ \\
\hline Chemical formula & $\mathrm{C}_{4} \mathrm{H}_{4} \mathrm{CINOS}$ & $\mathrm{C}_{4} \mathrm{H}_{5} \mathrm{NOS}$ & - \\
\hline Molecular weight & 149.59 & 115.16 & - \\
\hline Synonyms & $\begin{array}{l}\text { Chloromethylisothiazolinone; } \\
\text { Chloromethylthiazolone; } \\
\text { Methylchlorothiazolone }\end{array}$ & $\begin{array}{l}\text { 2-Methyl-4- } \\
\text { isothiazolin-2-one }\end{array}$ & $\begin{array}{l}\text { 5-Chloro-2-methyl-4-isothiazolin-3-one } \\
\text { and 2-methyl-4- isothiazolin-3-one, } \\
\text { 3:1 ratio; Chloromethylisothiazolione + } \\
\text { Methylisothiazolinone (75\% + 25\%); } \\
\text { CMIT/MIT or MCI/MIT; CIT/MIT }\end{array}$ \\
\hline
\end{tabular}


values and factors were selected through expert discussions to assess the potential risk factors associated with CMIT/MIT. Finally, based on the results of the risk assessment, we also evaluated the adequacy of current CMIT/ MIT regulations.

\section{PHYSICOCHEMICAL PROPERTIES OF CMIT/MIT}

Table 1 summarizes the physical and chemical properties, such as chemical formula and molecular weight, of CMIT, MIT and CMIT/MIT of CMIT/MIT, that were investigated (1).

\section{COMMERCIAL USE}

As mentioned above, CMIT/MIT is widely used as a preservative in cosmetics, paints, adhesives, detergents, and other industrial products. According to the European Union (EU) regulation, the permitted concentration limits of CMIT/MIT are up to $15 \mathrm{ppm}$ in cosmetics, up to $15 \mathrm{ppm}$ in paints, adhesives, and detergents, and over $5,000 \mathrm{ppm}$ in industrial biocides $(2,28)$.

Among the cosmetics manufactured in Korea, 2,110 of the 100,190 products containing CMIT/MIT comprise rinse-off products, such as shampoos, rinses, and body washes (29).

\section{HAZARD IDENTIFICATION}

As part of the risk assessment, we evaluated the toxicological profile of CMIT/MIT; this included general toxicity, topical toxicity, developmental/reproductive toxicity, genotoxicity, carcinogenicity, phototoxicity, and toxicokinetics (Table 2-4).

\section{General toxicity.}

- Acute toxicity: Several animal experiments demonstrated the oral lethal dose, $50 \%\left(\mathrm{LD}_{50}\right)$ to be 7.5 to 78.5 active ingredient (a.i.) $\mathrm{mg} / \mathrm{kg}$ in rats and 30 a.i. $\mathrm{mg} / \mathrm{kg}$ in rabbits (30-34). Acute oral toxicity experiments reported severe gastric irritation, lethargy, and ataxia to be the most common toxic effects (34). Dermal $\mathrm{LD}_{50}$ was calculated to be 141 a.i. $\mathrm{mg} / \mathrm{kg}$ in rats and 4.5 to 130 a.i. $\mathrm{mg} / \mathrm{kg}$ in several rabbit experiments (33-35). The intraperitoneal (IP) $\mathrm{LD}_{50}$ was found to be 4.3 to 4.6 a.i. $\mathrm{mg} / \mathrm{kg}$ in rats, whereas the inhalation $\mathrm{LD}_{50}$ was $0.15 \sim \geq 1.4$ a.i. $\mathrm{mg} / \mathrm{L}$ in other

Table 2. General toxicity of CMIT/MIT

\begin{tabular}{|c|c|c|c|c|c|c|}
\hline Studies & Route & Species & $\begin{array}{l}\text { Exposure } \\
\text { period }\end{array}$ & Dose & Results & References \\
\hline \multirow[t]{6}{*}{ Acute } & Oral & Rat & Single & - & $\mathrm{LD}_{50}: 7.5-78.5$ a.i. $\mathrm{mg} / \mathrm{kg}$ & $30-34$ \\
\hline & Oral & Rabbit & Single & - & $\mathrm{LD}_{50}: 30$ a.i. $\mathrm{mg} / \mathrm{kg}$ & 34 \\
\hline & Dermal & Rat & Single & - & $\mathrm{LD}_{50}: 141$ a.i. $\mathrm{mg} / \mathrm{kg}$ & 35 \\
\hline & Dermal & Rabbit & Single & - & $\mathrm{LD}_{50}: 4.5-130$ a.i. $\mathrm{mg} / \mathrm{kg}$ & 33,34 \\
\hline & IP & Rat & Single & - & $\mathrm{LD}_{50}: 4.3-4.6$ a.i. $\mathrm{mg} / \mathrm{kg}$ & 34 \\
\hline & Inhalation & Rat & Single & - & $\mathrm{LC}_{50}: 0.15 \sim>1.4$ a.i. $\mathrm{mg} / \mathrm{L}$ & 34,36 \\
\hline \multirow[t]{4}{*}{$\begin{array}{l}\text { Sub } \\
\text { acute }\end{array}$} & Oral & Rat & 2 weeks & $\begin{array}{l}0,0.82,2.5,8.2,24.4 \\
\text { a.i. } \mathrm{mg} / \mathrm{kg} \mathrm{bw} / \mathrm{day}\end{array}$ & $\begin{array}{l}\text { No treatment-related systemic toxicity } \\
\text { was observed }\end{array}$ & 34 \\
\hline & Oral & Dog & 2 weeks & $\begin{array}{l}\text { 0, 28, 84, 280, } 840 \text { a.i. } \\
\text { ppm } \\
(0,1.2,4.3,15,29 \text { a.i. } \\
\text { mg/kg bw/day, male }) \\
(0,1.3,3.5,12,38 \text { a.i. } \\
\text { mg/kg bw/day, female })\end{array}$ & $\begin{array}{l}\text { Slightly reduced food consumption at two } \\
\text { high concentrations (male, female) } \\
\text { Increased hematocrit value at a high con- } \\
\text { centration (male) } \\
\text { Decrease in leukocyte counts at two high } \\
\text { concentrations (female) } \\
\text { Slight decrease in blood glucose at a high } \\
\text { concentration (male, female) }\end{array}$ & 34 \\
\hline & Dermal & Rabbit & $\begin{array}{l}3 \text { weeks } \\
\text { (5 days/week) }\end{array}$ & $\begin{array}{l}0,0.56,2.8 \text { a.i. } \mathrm{mg} / \mathrm{kg} \\
\text { bw/day }\end{array}$ & $\begin{array}{l}\text { Moderate dermal irritation observed in } \\
\text { all treatment groups } \\
\text { No treatment-related systemic toxicity }\end{array}$ & 34 \\
\hline & Inhalation & Rat & $\begin{array}{l}2 \text { weeks } \\
(5 \text { days/week, } \\
6 \text { hr/day) }\end{array}$ & $\begin{array}{l}0,0.03,0.07,0.13 \text { a.i. } \\
\mathrm{mg} / \mathrm{L}\end{array}$ & $\begin{array}{l}\text { Weight gain reduced at two high concen- } \\
\text { trations } \\
\text { Death at low and high concentrations } \\
\text { (lesions: pulmonary hemorrhages and } \\
\text { swollen livers) } \\
\text { NOEL }<0.03 \text { a.i. mg/L }\end{array}$ & 34 \\
\hline
\end{tabular}


Table 2. Continued

\begin{tabular}{|c|c|c|c|c|c|c|}
\hline Studies & Route & Species & $\begin{array}{l}\text { Exposure } \\
\text { period }\end{array}$ & Dose & Results & References \\
\hline \multirow[t]{8}{*}{$\begin{array}{l}\text { Sub } \\
\text { chronic }\end{array}$} & Oral & Rat & 90 days & $\begin{array}{l}0,40-80,132-260 \\
400-800 \text { ppm }\end{array}$ & $\begin{array}{l}\text { No treatment-related systemic toxicity } \\
\text { was observed } \\
\text { NOEL: } 800 \mathrm{ppm} \text { ( } 29.1 \text { a.i. } \mathrm{mg} / \mathrm{kg} \mathrm{bw} / \\
\text { day) }\end{array}$ & 37 \\
\hline & Oral & Rat & 90 days & $0,25,75,225$ a.i. ppm & $\begin{array}{l}\text { Irritation of glandular stomach at a high } \\
\text { concentration } \\
\text { NOEL: } 75 \text { a.i. ppm ( } 6.28 \text { a.i. } \mathrm{mg} / \mathrm{kg} \text { bw/ } \\
\text { day [male]; } 10.8 \text { a.i. } \mathrm{mg} / \mathrm{kg} \text { bw/day } \\
\text { [female]) } \\
\text { No histopathological changes up to the } \\
\text { highest dose } \\
\text { NOAEL: } 225 \text { a.i. ppm }(16.3 \text { a.i. } \mathrm{mg} / \mathrm{kg} \\
\text { bw/ day [male]; } 24.7 \text { a.i. } \mathrm{mg} / \mathrm{kg} \text { bw/day } \\
\text { [female]) }\end{array}$ & 34,38 \\
\hline & Oral & Rat & 3 months & $\begin{array}{l}0,3,10,30 \text { a.i. } \mathrm{mg} / \mathrm{kg} \\
\text { bw/day }\end{array}$ & No treatment-related systemic toxicity & 34 \\
\hline & Oral & Dog & 3 months & $0,84,280,840$ a.i. ppm & No treatment-related systemic toxicity & 34,39 \\
\hline & Oral & Dog & 90 days & $\begin{array}{l}0,101,363,555 \text { a.i. } \mathrm{mg} / \\
\mathrm{kg} \text { diet }\end{array}$ & No treatment-related systemic toxicity & 40 \\
\hline & Dermal & Rat & 91 days & $\begin{array}{l}0,0.75,3.75,18.75 \mathrm{mg} / \\
\mathrm{kg} \text { bw/day }\end{array}$ & $\begin{array}{l}\text { Observation of erythema, desquamation, } \\
\text { oedema, atonia, and eschar formation } \\
\text { in all treatment groups } \\
\text { NOAEL: } \leq 0.104 \text { a.i. } \mathrm{mg} / \mathrm{kg} \text { bw/day } \\
\text { LOAEL: } \geq 0.104 \text { a.i. } \mathrm{mg} / \mathrm{kg} \text { bw/day }\end{array}$ & 41 \\
\hline & Dermal & Rabbit & $\begin{array}{l}13 \text { weeks } \\
\text { (5 days/week) }\end{array}$ & $\begin{array}{l}\text { 0, 100, 200, } 400 \text { a.i. } \\
\text { ppm }\end{array}$ & No treatment-related systemic toxicity & 34,42 \\
\hline & Inhalation & Rat & $\begin{array}{l}13 \text { weeks } \\
(6 \mathrm{hr} / \text { day, } \\
5 \text { days/week })\end{array}$ & $\begin{array}{l}\text { 0. } 0.34,1.15,2.64 \text { a.i. } \\
\mathrm{mg} / \mathrm{m}^{3}\end{array}$ & $\begin{array}{l}\text { Irritation of the respiratory tract at } 1.15 \\
\text { a.i. } \mathrm{mg} / \mathrm{m}^{3} \\
\text { NOEL: } 0.34 \text { a.i. } \mathrm{mg} / \mathrm{m}^{3} \\
\text { No histopathological changes up to the } \\
\text { highest dose } \\
\text { NOAEL: } 2.64 \text { a.i. } \mathrm{mg} / \mathrm{m}^{3}\end{array}$ & 43 \\
\hline
\end{tabular}

a.i., active ingredient; IP, intraperitoneal; $\mathrm{LD}_{50}$, lethal dose, 50\%; $\mathrm{LC}_{50}$, lethal concentration, 50\%; NOEL, no observed effect level; NOAEL, no observed adverse effect level; LOAEL, lowest observed adverse effect level.

studies $(34,36)$. IP administration of CMIT/MIT resulted in toxic signs, such as decreased motor activity and peritonitis, whereas inhalation of it resulted in toxic effects, such as dyspnea, salivation, and pulmonary congestion (34).

- Subacute toxicity: Rats were administered following concentrations of CMIT/MIT for 2 weeks to determine the subacute toxicity: $0,0.82,2.5,8.2$, and 24.4 a.i. $\mathrm{mg} / \mathrm{kg}$ bw/day. No treatment-related systemic toxicity was observed (34). However, another study reported toxicity in dogs treated with $0,28,84,280$, and 840 a.i. ppm for 2 weeks. A slight reduction in food consumption was reported at two high concentrations in both male and female dogs, and hematocrit values increased at high concentrations in males. In addition, leukocyte counts decreased at the two high concentrations in females, and blood glucose levels decreased slightly at high concentrations in both males and females (34). Rabbits treated with $0,0.56$, and 2.8 a.i. $\mathrm{mg} / \mathrm{kg}$ bw/day for 3 weeks showed moderate dermal irritation in all groups; however, no treatment-related systemic toxicity was observed (34). In rats exposed to CMIT/MIT via inhalation for 2 weeks at concentrations of $0,0.03$, 0.07 , and 0.13 a.i. $\mathrm{mg} / \mathrm{L}$, a reduction in weight gain was observed at two high concentrations, whereas death was observed at low and high concentrations. Moreover, lesions, such as pulmonary hemorrhages and swollen liver, were observed. Based on these observations, the no observed effect level (NOEL) was set at $<0.03$ a.i. $\mathrm{mg} / \mathrm{L}$ (34).

- Subchronic toxicity: To evaluate the subchronic toxicity, rats were administered following CMIT/MIT con- 
centrations: $0,40-80,132-260$, and 400-800 ppm for 90 days. No systemic toxicity was found to be associated with the treatment, and the NOEL was set at $800 \mathrm{ppm}$ (29.1 a.i. $\mathrm{mg} / \mathrm{kg}$ bw/day) (37). However, after rats were treated with $0,25,75$, and 225 a.i. ppm CMIT/MIT for 90 days, they showed irritation of the glandular stomach at 225 a.i. ppm. No histopathological changes were observed up to the highest concentration. As a result, the NOEL was set as 75 a.i. ppm, and the no observed adverse effect level (NOAEL) was set as 225 a.i. ppm $(34,38)$. Three independent experiments in rats and dogs treated with CMIT/MIT for approximately 3 months reported no treatment-related systemic toxicity $(34,39,40)$. After dermal administration of CMIT/MIT $(0,0.75,3.75$, and $18.75 \mathrm{mg} / \mathrm{kg}$ bw/day) in rats for 91 days, erythema, desquamation, edema, atonia, and eschar formation were observed in all treatment groups. Accordingly, the NOAEL was estimated to be below 0.104 a.i. $\mathrm{mg} / \mathrm{kg}$ bw/day, and the lowest observed adverse effect level (LOAEL) was estimated to be 0.104 a.i. $\mathrm{mg} / \mathrm{kg}$ bw/day or higher (41). No treatment-related systemic toxicity was observed in rabbits' skin at $0,100,200$, and 400 a.i. ppm after 13 weeks of treatment $(34,42)$. In another experiment, rats exposed to $0,0.34,1.15$, and 2.64 a.i. $\mathrm{mg} /$ $\mathrm{m}^{3}$ CMIT/MIT demonstrated irritation of respiratory tract at 1.15 a.i. $\mathrm{mg} / \mathrm{m}^{3}$, whereas no histopathological changes were observed up to the highest concentration. Therefore, the NOEL was set at 0.34 a.i. $\mathrm{mg} / \mathrm{m}^{3}$, and the NOAEL was restricted to 2.64 a.i. $\mathrm{mg} / \mathrm{m}^{3}$ (43) (Table 2).

Topical toxicity. Several skin sensitization tests using an occlusive patch were performed on rabbit skin. Treatment with CMIT/MIT concentration of 1.1 to 14.2 a.i.\% resulted in severe skin irritation. Results of another experiment at four different CMIT/MIT concentrations revealed no irritation at 0.0056 a.i.\%, moderate irritation at 0.28 a.i.\%, and severe irritation at 0.56 and 5.6 a.i.\% $(34,44,45)$.

Furthermore, ocular experiments conducted in rabbits using CMIT/MIT reported severe irritation at concentrations of 1.1 to 14 a.i.\%. Results of another series of experiments performed using four CMIT/MIT concentrations showed no irritation at concentrations from 0.056 to 0.01 a.i.\%, weak to moderate irritation at 0.28 a.i.\%, moderate to severe irritation from 0.56 to 1.7 a.i. $\%$, and severe irritation from 2.8 to 5.6 a.i.\%. In addition, cumulative irritation experiments performed in 12 rabbits using samples containing 0.0056 a.i.\% CMIT/MIT at a volume of $0.1 \mathrm{~mL}$ for 4 weeks revealed no irritation at 0.0056 a.i.\% of CMIT/MIT $(34,46,47)$.

In another experiment, the bovine cornea was treated with CMIT/MIT, MIT, or CMIT/1,2-benzisothiazolin-3-one (BIT) for $10 \mathrm{~min}$ to assess eye irritation (48). After the cornea was washed, it was placed in the complete minimum essential medium (cMEM) for more than $2 \mathrm{hr}$ (48). Corneal permeability was measured using the fluorine dye solution to confirm the final turbidity (48). The in vitro score (IVS) was calculated by measuring the turbidity and absorbance, and evaluated by a predictive model designed by Gautheron et al (49). IVS refers to the intensity of the stimulation; an IVS of 3 or more indicates presence of an irritant (49). The MIT/BIT $(21.8 \pm 3.2)$ and CMIT/MIT $(16.8 \pm 7.3)$ groups showed a stronger ocular stimulation than the MIT (9.3 \pm 5.3$)$ alone treatment group (48). Overall, these agents were considered to be mild eye irritants (48). In addition, a respiratory irritation experiment on rates determined the $50 \%$ respiratory rate decrease $\left(\mathrm{RD}_{50}\right)$ to be $69 \mu \mathrm{g} / \mathrm{L}(9.4$ a.i. $\mu \mathrm{g} / \mathrm{L})$ after a $407 \mu \mathrm{g} / \mathrm{L}$ CMIT/MIT treatment (50).

Skin sensitization. To evaluate the effects of CMIT/ MIT on skin sensitization, the local lymph node assay (LLNA) was utilized. Results of this test revealed the effective concentration (EC3 (\%)), i.e., the concentration at which the stimulation index of the test substance increases threefold or higher as compared to the control, to be 30 to $70 \mathrm{ppm}\left(0.75\right.$ to 2 a.i. $\left.\mu \mathrm{g} / \mathrm{cm}^{2}\right)$ after CMIT/MIT treatment $(51,52)$. In another study, the EC3 (\%) was estimated to be 1.2 and 2.1 a.i. $\mu \mathrm{g} / \mathrm{cm}^{2}(53,54)$. Based on these data, CMIT/MIT was identified as an extreme skin sensitizer in animals.

A number of skin sensitization experiments have also been performed in humans. Cardin et al. (55) performed a repeated patch test to assess the effects of CMIT/MIT in 1,450 individuals. Occlusive patches were induced thrice with CMIT/MIT per week for 3 weeks and maintained for $24 \mathrm{hr}$. CMIT/MIT was tested for a prototype concentration of 5 to $20 \mathrm{ppm}$ and for various products. As a result, no skin sensitization was observed in products containing less than $12.5 \mathrm{ppm}$ of CMIT/MIT, and only one or two cases of skin sensitization occurred in shampoos containing $12.5 \mathrm{ppm}$ and water containing $20 \mathrm{ppm}$ (55).

An occlusive patch test was also performed in nine volunteers. A patch containing 1, 2, 5, 10, 15, 25, 50, and 100 ppm of CMIT/MIT was applied on the volunteers for $48 \mathrm{hr}$. No skin reaction was observed at concentrations below $15 \mathrm{ppm}$. However, one patient treated with $25 \mathrm{ppm}$, six patients treated with $50 \mathrm{ppm}$, and nine patients treated with $100 \mathrm{ppm}$ of CMIT/MIT demonstrated a skin sensitization response. Accordingly, CMIT/MIT was evaluated as a skin sensitizer at high treatment concentrations (56).

In another study, an occlusive patch test using an aqueous solution containing $25 \mathrm{ppm}$ of CMIT/MIT was performed in 18 volunteers. The patches were placed on patients for $24 \mathrm{hr}, 3$ times a week for 3 weeks. One volunteer showed a skin sensitization reaction. A skin sensitization response also appeared when the applicant was rechallenged 6 weeks later. Based on these results, investigators determined that $25 \mathrm{ppm}$ of CMIT/MIT could cause skin sensitization (34). 
Based on a number of skin sensitization studies, the National Institute for Public Health and the Environment (RIVM) reported data comparing the mouse sensitization threshold by the LLNA test to the human sensitization threshold by the human sensitization test. In this report, the threshold for mice was set at $2.25 \mu \mathrm{g} / \mathrm{cm}^{2}$, whereas the threshold for humans was set at $1.25 \mu \mathrm{g} / \mathrm{cm}^{2}$ (57).

Developmental/reproductive toxicity. To determine the effects of CMIT/MIT on reproductive ability, rats were administered 30, 100, and 300 a.i. ppm of CMIT/MIT in drinking water. The control group was administered water and magnesium salt (Table 3). A total of 26 males and females were present in each group. The CMIT/MIT concentrations were administered to two generations of rats at
$0,2.8-4.4,8.5-11.8$, and $22.7-28.0$ a.i. $\mathrm{mg} / \mathrm{kg}$ bw/day in the first parental generation (P1), and 0, 4.3-5.5, 13.4-16.0, and $35.7-39.1$ a.i. $\mathrm{mg} / \mathrm{kg}$ bw/day in the second parental generation (P2). In the $\mathrm{P} 1$ and $\mathrm{P} 2$, concentration-dependent histopathological changes were observed in the stomach. At concentrations of 100 and 300 a.i. ppm, erosion, hyperplasia, and hyperkeratosis were observed. When compared to the control group, neither the female estrus cycle in the P1 and P2 nor the male sperm motility, shape, and number were affected. Moreover, no differences in the other reproductive endpoints compared to the control group were observed. In both generations, gastric irritation was observed at medium and high concentrations; thus, the parental NOAEL of CMIT/MIT was set at $30 \mathrm{ppm}$ a.i. (P1: 2.8-4.4 mg/kg bw/day; P2: 4.3-5.5 mg/kg bw/day).

Table 3. Developmental/reproductive toxicity of CMIT/MIT

\begin{tabular}{|c|c|c|c|c|c|}
\hline Route & Species & $\begin{array}{l}\text { Exposure } \\
\text { period }\end{array}$ & Dose & Results & References \\
\hline Oral & Rat & $\begin{array}{l}\text { Two } \\
\text { generations }\end{array}$ & $\begin{array}{l}\text { 0, 30, } 100,300 \text { a.i. ppm } \\
\text { (P1: } 2.8-4.4,8.5-11.8 \\
\text { 22.7-28.0 a.i. } \mathrm{mg} / \mathrm{kg} \\
\text { bw/day; } \mathrm{P} 2: 4.3-5.5, \\
\text { 13.4-16.0, 35.7-39.1 a.i. } \\
\mathrm{mg} / \mathrm{kg} \text { bw/day) }\end{array}$ & $\begin{array}{l}\text { Irritation in the stomach } \\
\text { Parental NOAEL: } 30 \text { a.i. ppm (P1: } 2.8-4.4 \text { a.i. } \mathrm{mg} / \mathrm{kg} \\
\text { bw/day; P2: } 4.3-5.5 \text { a.i. } \mathrm{mg} / \mathrm{kg} \text { bw/day) } \\
\text { No reproductive toxicity up to the highest treatment } \\
\text { concentration } \\
\text { Reproductive NOEL: } 300 \text { a.i. ppm (P1: } 22.7-28.0 \text { a.i. } \\
\text { mg/kg bw/day; P2: } 35.7-39.1 \text { a.i. } \mathrm{mg} / \mathrm{kg} \text { bw/day) }\end{array}$ & 58 \\
\hline Oral & Rat & 15 weeks & $0,25,75,225 \mathrm{ppm}$ & No reproductive toxicity observed & 34 \\
\hline Oral & Rat & $\begin{array}{l}\text { Days } 5-15 \\
\text { of gestation }\end{array}$ & $\begin{array}{l}0,1.5,4.5,15 \text { a.i. } \\
\mathrm{mg} / \mathrm{kg} \text { bw/day }\end{array}$ & $\begin{array}{l}\text { Dose-dependent death observation (low, } 1 / 25 ; \mathrm{mid} \text {, } \\
2 / 25 ; \text { high, } 3 / 25 \text { ) } \\
\text { No treatment-related reproductive changes - } \\
\text { No teratogenicity observed in all treatment groups } \\
\text { Developmental NOEL: }>15 \text { a.i. } \mathrm{mg} / \mathrm{kg} \text { bw } / \text { day }\end{array}$ & 59 \\
\hline Oral & Rat & - & - & $\begin{array}{l}\text { Reproductive NOAEL: } \geq 10 \text { a.i. } \mathrm{mg} / \mathrm{kg} \text { bw/day } \\
\text { Parental NOAEL: } \geq 10 \text { a.i. } \mathrm{mg} / \mathrm{kg} \text { bw/day } \\
\text { F1 NOAEL: } \geq 2.5 \text { a.i. } \mathrm{mg} / \mathrm{kg} \mathrm{bw} / \mathrm{day} \\
\text { F2 NOAEL: } \geq 2.5 \text { a.i. } \mathrm{mg} / \mathrm{kg} \text { bw/day }\end{array}$ & 60 \\
\hline Oral & Rat & - & - & $\begin{array}{l}\text { Parental NOAEL: } \leq 3.95 \text { a.i. } \mathrm{mg} / \mathrm{kg} \text { bw/day } \\
\text { Teratogenic NOAEL: } \geq 19.6 \text { a.i. } \mathrm{mg} / \mathrm{kg} \text { bw/day } \\
\text { Reproductive NOAEL: } \geq 19.6 \text { a.i. } \mathrm{mg} / \mathrm{kg} \text { bw/day }\end{array}$ & 61 \\
\hline Oral & Rabbit & $\begin{array}{l}\text { Days } 6-18 \\
\text { of gestation }\end{array}$ & $\begin{array}{l}0,1.5,4.4,13.3 \text { a.i. } \\
\mathrm{mg} / \mathrm{kg} \text { bw/day }\end{array}$ & $\begin{array}{l}\text { Dose-dependent death observation (low, } 5 / 15 ; \text { mid, } \\
\text { 12/15; high, 14/15) } \\
\text { Reduced number of surviving fetuses } \\
\text { Increased resorption sites and observed post } \\
\text { implantation losses } \\
\text { No teratogenicity observed in all groups }\end{array}$ & 34 \\
\hline Oral & Rabbit & - & - & $\begin{array}{l}\text { Developmental NOAEL: }>5.49 \text { a.i. } \mathrm{mg} / \mathrm{kg} \text { bw/day } \\
\text { Maternal and foetal NOAEL: } 1.41 \text { a.i. } \mathrm{mg} / \mathrm{kg} \text { bw/day }\end{array}$ & 62 \\
\hline Oral & Rabbit & - & - & $\begin{array}{l}\text { The highest dose based on severe maternal toxicity at } \\
20 \mathrm{mg} / \mathrm{kg} \text { bw/day } \\
\text { Maternal NOEL: } 2 \mathrm{mg} / \mathrm{kg} \text { bw/day } \\
\text { Developmental NOEL: } 8 \text { a.i. } \mathrm{mg} / \mathrm{kg} \text { bw/day }\end{array}$ & 63 \\
\hline
\end{tabular}

a.i., active ingredient; NOEL, no observed effect level; NOAEL, no observed adverse effect level; P1, first parental generation; P2, second parental generation. 
Table 4. Genotoxicity of CMIT/MIT

\begin{tabular}{|c|c|c|c|c|c|}
\hline Test methods & Species & Exposure period & Dose & Results & References \\
\hline $\begin{array}{l}\text { Reverse mutation test } \\
\text { (Ames test) }\end{array}$ & $\begin{array}{l}\text { Salmonella } \\
\text { typhimurium }\end{array}$ & - & - & $\begin{array}{l}\text { Positive in strain TA } 100 \\
\text { (with or without S9) }\end{array}$ & $64-69$ \\
\hline Gene mutation test & $\begin{array}{l}\text { Mouse lymphoma } \\
\text { cells }\end{array}$ & - & - & $\begin{array}{l}\text { CMIT/MIT increased } \\
\text { mutant frequencies by } \\
\text { up to } 10 \text { times }\end{array}$ & $70-72$ \\
\hline UDS assay & $\begin{array}{l}\text { Primary rat } \\
\text { hepatocytes }\end{array}$ & $20 \mathrm{hr}$ & $0.00375-7.5$ a.i. $\mu \mathrm{g} / \mathrm{mL}$ & - & 72,73 \\
\hline $\begin{array}{l}\text { Mammalian cell } \\
\text { chromosome } \\
\text { aberration test }\end{array}$ & $\begin{array}{l}\text { Chinese hamster } \\
\text { lung cells }\end{array}$ & - & $0.00045-0.12$ a.i. $\mu \mathrm{g} / \mathrm{mL}$ & - & 74 \\
\hline $\begin{array}{l}\text { Chromosome } \\
\text { aberration test }\end{array}$ & $\begin{array}{l}\text { Rat (bone marrow } \\
\text { cells) }\end{array}$ & 5 days & $\begin{array}{l}0,0.28,2.8,28 \text { a.i. } \mathrm{mg} / \\
\mathrm{kg} \text { bw/day }\end{array}$ & - & 75 \\
\hline $\begin{array}{l}\text { Chromosome } \\
\text { aberration test }\end{array}$ & $\begin{array}{l}\text { Mouse (bone } \\
\text { marrow cells) }\end{array}$ & $\begin{array}{l}\text { Single or } 5 \\
\text { consecutive days }\end{array}$ & Up to 30 a.i. $\mathrm{mg} / \mathrm{kg}$ & - & $76-78$ \\
\hline Micronucleus assay & Mice & $\begin{array}{l}\text { Single or } \\
\text { consecutive days }\end{array}$ & Up to $50 \mathrm{mg} / \mathrm{kg}$ bw & - & $79-81$ \\
\hline UDS assay & Rats & Single & Up to $500 \mathrm{mg} / \mathrm{kg}$ bw & - & 82,83 \\
\hline $\begin{array}{l}\text { Sex-linked recessive } \\
\text { lethal test }\end{array}$ & $\begin{array}{l}\text { Drosophila } \\
\text { melanogaster }\end{array}$ & - & $\begin{array}{l}\text { Up to } 86 \text { a.i./mL (feed); } \\
258 \text { a.i./mL (injection) }\end{array}$ & - & 72,84 \\
\hline
\end{tabular}

a.i., active ingredient; UDS, unscheduled DNA synthesis.

The NOEL for reproductive toxicity was set at $300 \mathrm{ppm}$ a.i. (P1: 22.7-28.0 mg/kg bw/day; P2: $35.7-39.1 \mathrm{mg} / \mathrm{kg}$ bw/day). No reproductive toxicity up to the highest concentration was noted (58).

In addition, CMIT/MIT was administered via drinking water to 10 male and 10 female rats per group for 15 weeks at concentrations of $0,25,75$, and $225 \mathrm{ppm}$. Following this, mating was performed within the same treatment group. No toxicity to parents and fetus was observed at 21 days after delivery (34).

Furthermore, oral administration experiments were performed in rats at 5 to 15 days of gestation. The experimental groups were treated with CMIT/MIT concentrations of $1.5,4.5$, and 15 a.i. $\mathrm{mg} / \mathrm{kg}$ bw/day, whereas the control group received distilled water. Twenty-five pregnant rats per group were selected in which the dose-dependent maternal toxicity was observed. One rat at low concentrations, two at medium concentrations, and three at high concentrations died due to wheezing, alopecia, and gastric irritation. No other reproductive or teratogenic toxicity was observed. Based on these results, a developmetal NOEL was selected at dose of greater than $15 \mathrm{mg} / \mathrm{kg}$ bw/day (59).

In addition, embryotoxic and fetotoxic effects were reported in rabbits at 6 to 18 days post-pregnancy. Fifteen rabbits per group were administered $0,1.5,4.4$, and 13.3 a.i. $\mathrm{mg} / \mathrm{kg}$ bw/day of CMIT/MIT. This study reported that 0,5 , 12 , and 14 rabbits per group, resepectively, were died at these concentrations due to development of ataxia, diarrhea, and severe gastric irritation. A decrease in the number of surviving fetuses, increase in the number of resorption sites, and loss at post-implantation stage were observed. No other treatment-related teratogenic toxicity was observed (34).

According to the data reported by SCCS (1), additional studies were conducted; however, no detailed information was provided (60-63).

Genotoxicity. A reverse mutation test (Ames test) using CMIT/MIT was performed in Salmonella typhimurium. Numerous studies have reported CMIT/MIT to mutate TA100 strain of $S$. typhimurium in the presence or absence of S9 (64-69). In addition, CMIT/MIT is also known to mutate TA98, TA102, TA1535, and TA1537 strains of $S$. typhimurium (68), and has a negative response in E. coli (69).

A positive effect by CMIT/MIT was observed in the gene mutation assay using mouse lymphoma cell line. The CMIT/MIT treatment concentration range was selected as nontoxic to $10 \%$ relative growth. As a result, CMIT/MIT increased mutant frequencies by up to 10 times (70-72).

Moreover, CMIT/MIT did not induce an unscheduled DNA synthesis (UDS). In this experiment, primary hepatocytes from rats were treated with CMIT/MIT at 0.00375 to 7.5 a.i. $\mu \mathrm{g} / \mathrm{mL}$ for 20 hours. Cytotoxicity was observed only at concentrations above 0.75 a.i. $\mu \mathrm{g} / \mathrm{mL}(72,73)$.

In vitro chromosomal aberration experiments using Chinese hamster lung fibroblasts were conducted where cells were treated with CMIT/MIT at concentrations of 0.00045 
to 0.12 a.i. $\mu \mathrm{g} / \mathrm{mL}$. Although toxicity was observed at 0.015 to 0.12 a.i. $\mu \mathrm{g} / \mathrm{mL}$, the number of chromosomal aberrations did not increase as compared to the control group (74).

A chromosome aberration test was also performed using the bone marrow cells of rats. Groups of five rats per group were administered $0,0.28,2.8$, and 28 a.i. $\mathrm{mg} / \mathrm{kg}$ bw/day of CMIT/MIT for 5 consecutive days. In this study, CMIT/ MIT did not induce chromosomal changes (75).

In addition, a chromosome aberration test and a micronucleus assay were performed in mice, and a UDS study was performed in rats (76-83). These studies also did not induce genotoxicity.

A gender-linked recessive lethal test was performed in Drosophila melanogaster. The number of lethal cases in the progeny after oral and injection treatment was examined. No mutagenesis in the experimental animals was reported $(72,84)$.

Several genotoxicity experiments showed positive in vitro results for CMIT/MIT. However, the data published by the United States Environmental Protection Agency (U.S. EPA) consider the in vitro studies in the mammalian system to predict genotoxicity as inappropriate (13).

Carcinogenicity. According to the reported data, two types of carcinogenicity studies were performed for CMIT/ MIT. First, CMIT/MIT was administered via drinking water to rats at concentrations of 30,100 , and 300 a.i. ppm for 2 years. The control group received water and magnesium salt. Ninety males and 80 females were present in each group. Blood and urine samples were evaluated at regular intervals throughout the study, and at the end of the experiment, histopathological examination was performed by autopsy. The survival rates at all doses in both male and female rats were found to be similar to those reported in the control group. No changes in physical, hematological, clinical chemistry, ophthalmological, or organ weight were observed during the duration of administration in any dose group. During the administration, no changes in body weight were observed in the dose groups, but a concentration-dependent decrease in water consumption was observed in the 30 a.i. ppm group $(0-22 \%)$, the 100 a.i. ppm group (3-30\%), and the 300 a.i. ppm group (15-40\%). This was attributed to the unpleasant taste of CMIT/MIT, not the salt, which acted as a drug stabilizer. No evidence of treatment-related neoplasms or systemic toxicity was observed, ruling out CMIT/MIT to be a carcinogen. Based on the observed gastric irritation in the stomach at 100 a.i. ppm and 300 a.i. ppm, the NOEL and NOAEL were determined to be 30 a.i. ppm and 300 a.i. ppm, respectively (85).

Dermal carcinogenicity studies were also conducted in mice for 30 months. Mice were administered 0 and 400 a.i. ppm of CMIT/MIT, and 1,000 a.i. ppm of 3-methylcholanthrene was selected as the positive control. Each treatment group consisted of 40 mice. CMIT/MIT was mixed with distilled water to obtain a total volume of $25 \mu \mathrm{L}$ and administered to the shaved dorsal skin of mice. At the end of this experiment, all animals were autopsied and histopathologically analyzed. All positive control groups died within 16 months due to development of squamous cell carcinoma of the skin that metastasized to the lungs, kidneys, and spleen. Focal hyperplasia and dermal inflammation were observed in the CMIT/MIT treatment group; however, no treatment-related neoplasms were observed. No other histopathological adverse effects on tissues and organs were reported. Based on these results, CMIT/MIT was found to be a non-carcinogenic compound (86).

Phototoxicity. To assess the phototoxicity of CMIT/ MIT on humans a patch of $2 \mathrm{~cm}^{2}$ containing 15 a.i. ppm of CMIT/MIT was applied to the forearms of 2 males and 23 females for $24 \mathrm{hr}$. After this, one arm was exposed to ultraviolet A (UV-A) $\left(4,400 \mu \mathrm{W} / \mathrm{cm}^{2}\right.$ wavelength) for $15 \mathrm{~min}$ (stimulated). Stimulated and non-stimulated skin was examined immediately after irradiation, and 24, 48, and $72 \mathrm{hr}$ after irradiation. The tanning effects of the irradiated sites were also investigated after 1 week. According to the results obtained, no phototoxic effect by CMIT/MIT on human skin was observed (87).

- Toxicokinetics: To study the kinetics of CMIT/MIT after its administration, two pairs of male and female rats were orally administered CMIT/MIT in liquid form for 7 days. The absorption, distribution, and excretion of CMIT/ MIT were studied. After 7 days, a total of 25 organs were extracted, and the distribution of CMIT/MIT was examined by radiography. CMIT/MIT was found to be uniformly distributed in animals, with the highest residues present in the digestive and excretory organs. CMIT/MIT was detected at concentrations as low as 0.12 to $0.5 \mathrm{ppm}$ in the brain, spinal cord, and gonads. Most of it (87 to $93 \%$ ) was excreted in the form of urine or feces. The halflife of CMIT/MIT was determined to be less than 1 day. There were no metabolic differences based on gender, and the metabolic rate of CMIT was slightly less than that of MIT. This study concluded that CMIT/MIT is readily absorbed in the organs; however, most of it is excreted within a day and only small amounts of it are distributed in the tissues $(34,88)$.

Further experiments were performed to confirm the absorption and disposition of CMIT/MIT by intravenous (IV) or dermal administration in rats. It was observed that CMIT/MIT was rapidly distributed in the blood, liver, kidneys, and testes when administered via IV, as evident from its rapid clearance from plasma within $96 \mathrm{hr}$ with only $29 \%$ of the dose remaining in the plasma. This is because CMIT/MIT binds to hemoglobin and is slowly removed by the liver and spleen. By $96 \mathrm{hr}$, excretion in the form of feces, urine, and respiration was 35,31 , and $4 \%$ of the ini- 
tial dose, respectively. Skin absorption studies estimated the absorption rate in rats to be up to $94 \%$. In addition, systemic bioavailability was evaluated to be significantly lower (89).

A concentration range-finding study of CMIT/MIT was conducted in rats by administering the compound via skin, oral, and IV routes. In this experiment, the skin absorption rate was estimated to be 26 to $43 \%$ depending on the concentration. While most CMIT/MIT was released less than $24 \mathrm{hr}$ after its oral administration, a majority of it could be released only after more than $48 \mathrm{hr}$ when administered transdermally. In addition, CMIT/MIT and its metabolites were found to interact strongly with erythrocytes. In conclusion, this study found no concentrationdependent significant differences in skin absorption of CMIT/MIT (90). Based on these results, metabolite profiles of CMIT/MIT were studied in rats. After oral administration, 50 to $77 \%$ of CMIT/MIT was excreted in urine and 23 to $54 \%$ in feces after $24 \mathrm{hr}$. In the skin exposure experiment, 20 to $28 \%$ of CMIT/MIT was excreted in the urine, whereas 1 to $2 \%$ of CMIT/MIT was excreted in the feces. Thus, exposure to skin showed a much slower elimination rate as compared to oral exposure. According to the results of this experiment, no differences in the metabolic profile of CMIT/MIT were observed when administered through different routes (91).

In another study, a skin absorption experiment using a blood sample from rabbits was performed. Occlusion patches were repeatedly treated with CMIT/MIT, and blood was collected up to $55 \mathrm{hr}$ after treatment. The results demon- strated no CMIT/MIT in the blood (34).

Eight in vitro studies to analyze skin absorption rate of CMIT/MIT were conducted. Rat skin exposed to CMIT/ MIT was extracted at several time intervals and rate of skin absorption was measured in a Franz diffusion cell. The amount of CMIT/MIT that bound or passed through the skin was calculated. The skin absorption rate for CMIT/MIT was calculated to be 99 and $117 \%$ at 3 and $6 \mathrm{hr}$, respectively. The maximum skin absorption rate after 48 to $96 \mathrm{hr}$ was found to be $80 \%$ (92).

\section{HAZARD DETERMINATION}

We next reviewed the studies on the non-cancer risk assessment and skin sensitization risk assessment of CMIT/MIT conducted according to the reported toxicity values. The cancer risk assessment of CMIT/MIT was not performed, because it is not classified as a carcinogen. The toxicity reference value for the non-cancer risk assessment had a NOAEL of $2.8 \mathrm{mg} / \mathrm{kg}$ bw/day obtained from the two-generation reproductive toxicity study in rats (58). The toxicity reference value for skin sensitization risk assessment had a NESIL of $1.25 \mu \mathrm{g} / \mathrm{cm}^{2} /$ day obtained from human repeated insult patch test (HRIPT) (57).

\section{EXPOSURE ASSESSMENT}

To determine the extent of exposure to CMIT/MIT among Korean population as part of cosmetic usage, a study assessed the skin absorption rate, product concen-

Table 5. Daily usage and total daily usage by cosmetics products in the Korean population

\begin{tabular}{clccc}
\hline \hline Type of use & \multicolumn{1}{c}{ Product } & $\begin{array}{c}\text { Usage } \\
(\mathrm{g} / \text { day })^{\mathrm{a}}\end{array}$ & $\begin{array}{c}\text { Applied body surface } \\
\text { area }\left(\mathrm{cm}^{2}\right)^{\mathrm{b}}\end{array}$ & $\begin{array}{c}\text { Usage considering body } \\
\text { surface } \operatorname{area}\left(\mathrm{mg} / \mathrm{cm}^{2} / \mathrm{day}\right)\end{array}$ \\
\hline Rinse-off and hair & Shower gel & 0.10 & 17,500 & 0.005714 \\
cleansing products & Hand wash soap & 0.24 & 860 & 0.27907 \\
& Shampoo & 0.09 & 1,440 & 0.0625 \\
& Hair conditioner & 0.06 & 1,440 & 0.041667 \\
\hline Leave-on and & Body lotion & 5.48 & 15,670 & 0.349713 \\
hair care products & Face cream & 1.76 & 565 & 3.115044 \\
& Hand cream & 1.38 & 860 & 1.604651 \\
& Non-spraying deodorant & 2.33 & 200 & 0.277228 \\
& Hair styling & 0.28 & 1,010 & 0.261143 \\
\hline Makeup products & Wet wipe & 4.57 & 17,500 & 0.530973 \\
& Liquid foundation & 0.30 & 565 & 0.371681 \\
& Makeup remover & 0.21 & 565 & 0.833333 \\
& Eye makeup & 0.02 & 24 & 18.75 \\
& Mascara & 0.03 & 1.6 & 10.41667 \\
\hline & Lipstick & 0.05 & 4.8 & 3.125 \\
\hline
\end{tabular}

${ }^{a}$ 2014-2016 advanced evaluation of cosmetics risk assessment in Korea (93).

${ }^{\mathrm{b}}$ Refer to body surface data in Bremmer et al (96). 
Table 6. Estimation of systemic exposure dosage (SED) by cosmetics usage (non-cancer)

\begin{tabular}{cccccc}
\hline \hline Cosmetics type & $\begin{array}{c}\text { Concentration of CMIT/MIT } \\
\text { in product (\%) }\end{array}$ & $\begin{array}{c}\text { Cosmetics } \\
\text { usage (g/day) }\end{array}$ & $\begin{array}{c}\text { Skin absorption rate } \\
\text { of CMIT/MIT (\%) }\end{array}$ & $\begin{array}{c}\text { Body weight } \\
(\mathrm{kg})\end{array}$ & $\begin{array}{c}\text { SED } \\
(\mathrm{mg} / \mathrm{kg} \mathrm{bw} / \mathrm{day})^{\mathrm{b}}\end{array}$ \\
\hline $\begin{array}{c}\text { Representative } \\
\text { type cosmetics }\end{array}$ & 0.0015 & 16.9 & 100 & 60 & 0.00423 \\
\hline
\end{tabular}

SED, systemic exposure dosage.

${ }^{a}$ Due to the high standard deviation of the results in the human skin test, the skin absorption rate cannot be accurately confirmed; thus, the skin absorption rate is $100 \%$ (1).

${ }^{\mathrm{b}} \mathrm{SED}=$ cosmetics use $(\mathrm{mg} /$ day $) \times$ concentration of cosmetics ingredient in cosmetics $(\%) \times$ skin absorption rate (\%) of target ingredient $\div 60 \mathrm{~kg}$.

Table 7. Consumer exposure level (CEL) based on cosmetics consumption (skin sensitization)

\begin{tabular}{lccc}
\hline \hline Cosmetics type & $\begin{array}{c}\text { Concentration of CMIT/MIT } \\
\text { in product }(\%)\end{array}$ & $\begin{array}{c}\text { Cosmetics usage } \\
\left(\mathrm{mg} / \mathrm{cm}^{2}\right)\end{array}$ & $\begin{array}{c}\text { CEL } \\
\left(\mu \mathrm{g} / \mathrm{cm}^{2}\right)^{\mathrm{a}}\end{array}$ \\
\hline $\begin{array}{l}\text { Representative type cosmetics } \\
\text { Rinse-off products }\end{array}$ & 0.0015 & 51.6744 & 0.77512 \\
& & 0.3890 & 0.00584 \\
\hline
\end{tabular}

CEL, consumer exposure level.

${ }^{\mathrm{a}} \mathrm{CEL}=$ Use amount of cosmetics considering body surface area $\left(\mu \mathrm{g} / \mathrm{cm}^{2}\right) \times$ concentration of cosmetics of target component $(\%) / 100$.

tration, and body weight as per the available cosmetic risk assessment guidelines (93). The amount of cosmetics used was based on the actual usage of each product by the Korean population, determined from the advanced evaluation of cosmetic risk assessment conducted from 2014 to 2016 in Korea (Table 5) (93). In addition, based on actual data, cosmetics usage based on body surface area was calculated (Table 5) (93). Exposure scenarios were evaluated assuming daily use of 16 representative cosmetic products, such as body lotion or daily use of rinse-off products. The systemic exposure dosage (SED) through the skin was calculated using the following equation (Eq. 1):

$$
\begin{gathered}
\mathrm{SED}(\mathrm{mg} / \mathrm{kg} \mathrm{bw} / \text { day })=\mathrm{A}(\mathrm{g} / \text { day }) \times 1,000 \mathrm{mg} / \mathrm{g} \\
\times \mathrm{C}(\%) \times \mathrm{DA}(\%) / \mathrm{BW}(\mathrm{kg}),
\end{gathered}
$$

where

"SED" is systemic exposure dosage, " $\mathrm{A}$ " is daily usage of cosmetics, "C (\%)" is the maximum allowable concentration in the product, DA (\%) is dermal absorption rate, and BW is body weight.

The SED through the skin was calculated assuming that all representative cosmetics containing $0.0015 \%$ of CMIT/ MIT were used during the day. Therefore, cosmetics usage was determined to be $16.9 \mathrm{~g} /$ day. According to the data reported by SCCS (1), several in vitro and in vivo skin absorption experiments on CMIT/MIT were performed. However, since CMIT/MIT consists of two active ingredients, it was difficult to accurately evaluate the skin absorption rate, resulting in a standard deviation (1). Therefore, this study considered $100 \%$ skin absorption to be the worst scenario. Body weight was assumed to be $60.0 \mathrm{~kg}$, which is the average adult weight. As a result, the SED of CMIT/ MIT through the skin was calculated to be $0.00423 \mathrm{mg} / \mathrm{kg}$ bw/day (Table 6). In addition, the consumer exposure level (CEL) for the skin sensitization risk assessment was calculated using Eq. (2).

$$
\begin{gathered}
\mathrm{CEL}\left(\mu \mathrm{g} / \mathrm{cm}^{2} / \text { day }\right)=\mathrm{A}\left(\mathrm{mg} / \mathrm{cm}^{2} / \text { day }\right) \\
\times 1,000 \mu \mathrm{g} / \mathrm{mg} \times \mathrm{C}(\%),
\end{gathered}
$$

where

"CEL" is consumer exposure level, " $\mathrm{A}$ " is daily use of cosmetics considering the body surface area, and " $\mathrm{C}(\%)$ " is the maximum allowable concentration in the product.

The CEL was calculated assuming that all representative cosmetics or rinse-off products containing $0.0015 \%$ CMIT/MIT were used during the day. Therefore, the cosmetic use considering the body surface area was determined to be $51.6744 \mathrm{mg} / \mathrm{cm}^{2} /$ day or $0.3890 \mathrm{mg} / \mathrm{cm}^{2} /$ day. As a result, CEL was calculated to be $0.77512 \mu \mathrm{g} / \mathrm{cm}^{2} /$ day for all representative cosmetics products and $0.00584 \mu \mathrm{g} /$ $\mathrm{cm}^{2} /$ day for only rinse-off products (Table 7).

\section{RISK CHARACTERIZATION}

A study confirmed the results obtained in the risk assessment studies through the calculation of the margin of safety (MOS) (93). In the non-cancer risk assessment category, MOS was calculated as the NOAEL/SED, and a value of 100 or more was considered to be safe (93). It was estimated to be 633 using a NOAEL of $2.8 \mathrm{mg} / \mathrm{kg}$ bw/ day and SED of $0.00423 \mathrm{mg} / \mathrm{kg}$ bw/day (Table 8 ). These results indicated that no risk of sensitization existed at concentrations below $0.0015 \%$ of CMIT/MIT contained in 
Table 8. Noncancer risk assessment of CMIT/MIT

\begin{tabular}{|c|c|c|c|c|c|}
\hline Cosmetics type & $\begin{array}{c}\text { Concentration of CMIT/MIT } \\
\text { in product }(\%)\end{array}$ & $\begin{array}{l}\text { Cosmetics usage } \\
\text { (g/day) }\end{array}$ & $\begin{array}{c}\text { SED } \\
(\mathrm{mg} / \mathrm{kg} \text { bw/day })\end{array}$ & $\begin{array}{c}\text { NOAEL } \\
(\mathrm{mg} / \mathrm{kg} \text { bw/day) }\end{array}$ & $\operatorname{MOS}^{\mathrm{a}}$ \\
\hline Representative type cosmetics & 0.0015 & 16.9 & 0.00423 & 2.8 & 662.7 \\
\hline
\end{tabular}

SED, systemic exposure dosage; NOAEL, no observed adverse effect level; MOS, margin of safety.

${ }^{\text {a } M a r g i n}$ of safety $(M O S)=$ NOAEL $\div$ SED $\geq 100$ : safety.

Table 9. Skin sensitization risk assessment of CMIT/MIT

\begin{tabular}{lcccccc}
\hline \hline Cosmetics type & $\begin{array}{c}\text { Concentration of CMIT/MIT } \\
\text { in product (\%) }\end{array}$ & $\begin{array}{c}\text { NESIL } \\
\left(\mu \mathrm{g} / \mathrm{cm}^{2}\right)\end{array}$ & $\mathrm{SAF}^{\mathrm{a}}$ & $\begin{array}{c}\mathrm{AEL} \\
\left(\mu \mathrm{g} / \mathrm{cm}^{2}\right)^{\mathrm{b}}\end{array}$ & $\begin{array}{c}\mathrm{CEL} \\
\left(\mu \mathrm{g} / \mathrm{cm}^{2}\right)\end{array}$ & AEL/CEL $^{\mathrm{c}}$ \\
\hline $\begin{array}{l}\text { Representative type cosmetics } \\
\text { Rinse-off products }\end{array}$ & 0.0015 & 1.25 & 300 & 0.00417 & 0.77512 & 0.00538 (Not acceptable) \\
\hline
\end{tabular}

NESIL, no expected sensitization induction level; SAF, sensitization assessment factor; AEL, acceptable exposure level; CEL, consumer exposure level; MOS, margin of safety.

${ }^{a}$ SAF: 300 = interindividual: 10, matrix: 3, product use: 10; SAF: 100 = interindividual: 10, matrix: 3, product use: 3 (94).

${ }^{\mathrm{b}} \mathrm{AEL}=\mathrm{NESIL/SAF}$.

${ }^{\mathrm{C}} \mathrm{AEL} \div \mathrm{CEL} \geq 1$ : safety.

all representative cosmetics products. In the skin sensitization risk assessment, MOS was calculated as AEL/CEL and was considered safe when the AEL/CEL ratio was 1 or more (93). Here, AEL was calculated as the NESIL/ skin sensitization assessment factor (SAF), which was determined to be 300 when all representative cosmetics products were considered; it was 100 when only rinse-off products were considered (94). Based on an AEL of $0.00417 \mu \mathrm{g} / \mathrm{cm}^{2} /$ day and CEL of $0.77512 \mu \mathrm{g} / \mathrm{cm}^{2} /$ day or AEL of $0.0125 \mu \mathrm{g} / \mathrm{cm}^{2} /$ day and CEL of $0.00584 \mu \mathrm{g} / \mathrm{cm}^{2} /$ day, AEL/CEL values for the skin sensitization risk assessment were calculated to be 0.00538 and 2.14225 , respectively (Table 9). These results indicated the possibility of skin sensitization with all representative cosmetics products containing $0.0015 \%$ CMIT/MIT. However, no risk of skin sensitization was observed if only rinse-off products containing 0.0015\% CMIT/MIT were used.

\section{SUMMARY AND CONCLUSION}

In the present study, we performed a risk assessment of CMIT/MIT, a widely used preservative in cosmetic industry, to confirm its appropriateness for use as per the current safety standards. The results of the non-cancer toxicity assessment in a two-generation reproductive toxicity test revealed an NOAEL of $2.8 \mathrm{mg} / \mathrm{kg}$ bw/day, whereas the skin sensitization toxicity test determined the NESIL to be $1.25 \mu \mathrm{g} / \mathrm{cm}^{2} /$ day for humans $(57,58)$. When considering of all types of cosmetics, the MOS of non-cancer risk assessment was over 100; however, the AEL/CEL ratio of skin sensitization risk assessment was less than 1, indicating skin sensitization could be a possibility. The AEL/CEL ratio of skin sensitization was calculated to be 2.14225 for rinse-off cosmetics, indicating absence of any dermal risk.
In addition, the results of the risk assessment were compared to those of the international risk assessment agency. SCCS (1) selected the NOAEL as $2.8 \mathrm{mg} / \mathrm{kg}$ bw/day for the CMIT/MIT according to the two-generation reproductive toxicity study in rats. In addition, after evaluating daily rinse-off products containing $0.0015 \%$ of CMIT/ MIT, the MOS was calculated to be 7,368, and no safety concern was determined (1). In addition, the RIVM (57) recommends a quantitative risk assessment of skin sensitizers as a method to ensure safety against skin sensitization. A risk assessment for skin sensitization was performed on 2 to $15 \mathrm{ppm}$ of CMIT/MIT in body shampoo/gel, liquid soap, bubble bath, body lotion/cream, shampoo, and eau de toilette. According to the results, the skin sensitization AEL/CEL of the eau de toilette was calculated to be 0.005 , which the RIVM (57) considered a safety concern. The CIR did not perform a quantitative risk assessment; however, CMIT/MIT was evaluated as safe at concentrations of $15 \mathrm{ppm}$ for rinse-off products and $7.5 \mathrm{ppm}$ for leave-on products based on the cumulative patch test for humans $(13,95)$.

At present, CMIT/MIT is widely used as a preservative for cosmetics in Korea and Europe $(16,17)$. In addition, CMIT/MIT serves as a raw material in rinse-off products at a concentration below $0.0015 \%$; however, its use is prohibited in other products $(16,17)$. Based on the results of the risk assessment performed in the present study, the current CMIT/MIT regulatory values used in the cosmetics industry are evaluated as appropriate.

\section{ACKNOWLEGMENTS}

This review was supported by a grant (14172MFDS975) from the Ministry of Food and Drug Safety in 2014. 


\section{CONFLICT OF INTEREST}

The authors have no conflict of interest to disclose.

Received February 12, 2019; Revised March 4, 2019; Accepted March 5, 2019

\section{REFERENCES}

1. SCCS (Scientific Committee on Consumer Safety) (2009) Opinion on the Mixture of 5-Chloro-2-Methylisothiazolin3(2H)-One and 2-Methylisothiazolin-3(2H)-One. COLIPA $n^{0}$ P56. SCCS/1238/09.

2. Aerts, O., Goossens, A., Lambert, J. and Lepoittevin, J.P. (2017) Contact allergy caused by isothiazolinone derivatives: An overview of non-cosmetic and unusual cosmetic sources. Eur. J. Dermatol., 27, 115-122.

3. Castanedo-Tardana, M.P. and Zug, K.A. (2013) Methylisothiazolinone. Dermatitis, 24, 2-6.

4. Law, A.B., Moss, J.N. and Lashen, E.S. (1984) Kathon-CG: a new single component, broad spectrum preservative for cosmetics and toiletries. In Cosmetic and Drug Preservation. Principles and Practice (Karaba, J.J. Ed.). Marcel Decker, New York, pp. 129-141.

5. Lundov, M.D., Krongaard, T., Menné, T.L. and Johansen, J.D. (2011) Methylisothiazolinone contact allergy: a review. Br. J. Dermatol., 165, 1178-1182.

6. Williams, T. (2007) The mechanism of action of isothiazolinone biocides. PowerPlant Chemistry, 9, 14-22.

7. de Groot, A.C., Liem, D.H., Nater, J.P. and van Ketel, W.G. (1985) Patch tests with fragrance materials and preservatives. Contact Dermatitis, 12, 87-92.

8. de Groot, A.C., Liem, D.H. and Weyland, J.W. (1985) Kathon CG: cosmetic allergy and patch test sensitization. Contact Dermatitis, 12, 76-80.

9. Schnuch, A., Lessmann, H., Geier, J. and Uter, W. (2011) Contact allergy to preservatives. Analysis of IVDK data 1996-2009. Br. J. Dermatol., 164, 1316-1325.

10. Thyssen, J.P., Engkilde, K., Lundov, M.D., Carlsen, B.C., Menné, T. and Johansen, J.D. (2010) Temporal trends of preservative allergy in Denmark (1985-2008). Contact Dermatitis, 62, 102-108.

11. Wilkinson, J.D., Shaw, S., Andersen, K.E., Brandao, F.M., Bruynzeel, D.P., Bruze, M., Camarasa, J.M., Diepgen, T.L., Ducombs, G., Frosch, P.J., Goossens, A., Lachappelle, J.M., Lahti, A., Menné, T., Seidenari, S., Tosti, A. and Wahlberg, J.E. (2002) Monitoring levels of preservative sensitivity in Europe: A 10-year overview (1991-2000). Contact Dermatitis, 46, 207-210.

12. EU (European Union) (1989) Eleventh Commission Directive of 21 February 1989 adapting to technical progress Annexes II, III, IV, V, VI and VII to Council Directive 76/ 768/EEC on die approximation of die laws of the Member States relating to cosmetic products. 89/174/EEC. Off. $J$. Eur. Commun., 64, 10-14.

13. CIR (Cosmetic Ingredient Review) (1992) Final report on the safety assessment of methylisothiazolinone and methylchloroisothiazolinone. Int. J. Toxicol., 11, 75-128.
14. Uter, W., Aberer, W., Armario-Hita, J.C., Fernandez-Vozmediano, J.M., Ayala, F., Balato, A., Bauer, A., Ballmer-Weber, B., Beliauskiene, A., Fortina, A.B., Bircher, A., Brasch, J., Chowdhury, M.M., Coenraads, P.J., Schuttelaar, M.L., Cooper, S., Czarnecka-Operacz, M., Zmudzinska, M., Elsner, P., English, J.S., Frosch, P.J., Fuchs, T., García-Gavín, J., Fernández-Redondo, V., Gawkrodger, D.J., Giménez-Arnau, A., Green, C.M., Horne, H.L., Johansen, J.D., Jolanki, R., Pesonen, M., King, C.M., Krêcisz, B., Chomiczewska, D., Kiec-Swierczynska, M., Larese, F., Mahler, V., Ormerod, A.D., Peserico, A., Rantanen, T., Rustemeyer, T., SánchezPérez, J., Sansom, J.E., Silvestre, J.F., Simon, D., Spiewak, R., Statham, B.N., Stone, N., Wilkinson, M. and Schnuch, A. (2012) Current patch test results with the European baseline series and extensions to it from the 'European Surveillance System on Contact Allergy' network, 2007-2008. Contact Dermatitis, 67, 9-19.

15. Warshaw, E.M., Belsito, D.V., Taylor, J.S., Sasseville, D., DeKoven, J.G., Zirwas, M.J., Fransway, A.F., Mathias, C.G., Zug, K.A., DeLeo, V.A., Fowler, J.F. Jr., Marks, J.G., Pratt, M.D., Storrs, F.J. and Maibach, H.I. (2013) North American Contact Dermatitis Group patch test results: 2009-2010 study period. Dermatitis, 24, 50-59.

16. MFDS (Ministry of Food and Drug Safety) (2017) Regulations on Safety Standards for Cosmetics. Available from: http://mfds.go.kr/brd/m_211/down.do?brd_id=data0005\&seq= $13674 \&$ data_tp=A\&file_seq $=1 /$.

17. EU (European Union) (2018) Annex V, Last Update: 23/11/ 2018. List of Preservatives Allowed in Cosmetic Products. Available from: http://ec.europa.eu/growth/tools-databases/ cosing/pdf/COSING_Annex\%20V_v2.pdf/.

18. Lim, D.S., Choi, S.M., Kim, K.B., Yoon, K., Kacew, S., Kim, H.S. and Lee, B.M. (2018) Determination of fragrance allergens and their dermal sensitization quantitative risk assessment (QRA) in 107 spray perfumes. J. Toxicol. Environ. Health $A, \mathbf{8 1}, 1173-1185$.

19. Lim, D.S., Roh, T.H., Kim, M.K., Kwon, Y.C., Choi, S.M., Kwack, S.J., Kim, K.B., Yoon, S., Kim, H.S. and Lee, B.M. (2018) Risk assessment of N-nitrosodiethylamine (NDEA) and N-nitrosodiethanolamine (NDELA) in cosmetics. J. Toxicol. Environ. Health A, 81, 465-480.

20. Lim, D.S., Roh, T.H., Kim, M.K., Kwon, Y.C., Choi, S.M., Kwack, S.J., Kim, K.B., Yoon, S., Kim, H.S. and Lee, B.M. (2018) Non-cancer, cancer, and dermal sensitization risk assessment of heavy metals in cosmetics. J. Toxicol. Environ. Health A, 81, 432-452.

21. Kim, D.H., Choi, S.M., Lim, D.S., Roh, T., Kwack, S.J., Yoon, S., Kim, M.K., Yoon, K.S., Kim, H.S., Kim, D.W. and Lee, B.M. (2018) Risk assessment of endocrine disrupting phthalates and hormonal alterations in children and adolescents. J. Toxicol. Environ. Health A, 81, 1150-1164.

22. Oliveira Resende, A.P., Santos, V.S.V., Campos, C.F., Morais, C.R., de Campos Júnior, E.O., Oliveira, A.M.M. and Pereira, B.B. (2018) Ecotoxicological risk assessment of contaminated soil from a complex of ceramic industries using earthworm Eiseniafetida. J. Toxicol. Environ. Health A, 81, 10581065.

23. Kim, D.Y., Kim, J.H., Lee, J.C., Won, M.H., Yang, S.R., Kim, H.C. and Wie, M.B. (2019) Zinc oxide nanoparticles 
exhibit both cyclooxygenase- and lipoxygenase-mediated apoptosis in human bone marrow-derived mesenchymal stem cells. Toxicol. Res., 35, 83-91.

24. Kim, J.Y., Lee, J.H., Shin, S.J., Cho, A.R. and Heo, Y. (2018) Molecular mechanism of atopic dermatitis induction following sensitization and challenge with 2,4-dinitrochlorobenzene in mouse skin tissue. Toxicol. Res., 34, 7-12.

25. Nohmi, T. (2018) Thresholds of genotoxic and non-genotoxic carcinogens. Toxicol. Res., 34, 281-290.

26. Kim, Y.S., Chung, Y.H., Seo, D.S., Choi, H.S. and Lim, C.H. (2018) Twenty-eight-day repeated inhalation toxicity study of aluminum oxide nanoparticles in male Sprague-Dawley rats. Toxicol. Res., 34, 343-354.

27. Park, J.Y., Lee, H.D. and Park, K.S. (2018) Mixture toxicity of methylisothiazolinone and propylene glycol at a maximum concentration for personal care products. Toxicol. Res., 34, 355-361.

28. Friis, U.F., Menné, T., Flyvholm, M.A., Bonde, J.P., Lepoittevin, J.P., Le Coz, C.J. and Johansen, J.D. (2014) Isothiazolinones in commercial products at Danish workplaces. Contact Dermatitis, 71, 65-74.

29. KCA (Korea Cosmetic Association) (2015) List of Raw Materials.

30. RH (Rohm and Haas) (1991) Report No. 91R-019. Kathon WT $1.5 \%$; Acute Oral Toxicity Study in Male and Female Rats.

31. PE (Pharmakon Europe) (1994) Report No. 53293, "Test to Evaluate the Acute Toxicity following a single oral administration (LD50) in the Rat of Acticide 14", Sponsor: Thor Chemicals (UK) Limited, 28.03.94.

32. PFGB (PFG Biopharm) (1998) Study No. 009 Tox 97, "Acute Oral Toxicity of Acticide 14 (L) in the rat", Sponsor: Thor Chemie GmbH, 14-01-98.

33. RH (Rohm and Haas) (1999) Report No. 80R-196A. Kathon ${ }^{\circledR}$ CG Biocide Acute Oral Toxicity Study in Rats and Acute Dermal Toxicity Study in Rabbits.

34. RH (Rohm and Haas) (1984) Evaluation of the Toxicity of Kathon Biocide. Toxicology Dept., Spring House, PA. (unpublished data).

35. PE (Pharmakon Europe) (1994) Report No. 53193, "Test to Evaluate the Acute Toxicity Following a Single Cutaneous Application (Limit Test) in the Rat of Acticide 14", Sponsor: Thor Chemicals (UK) Limited, 28.03.94.

36. RH (Rohm and Haas) (1991) Report No. 91R-018. Kathon ${ }^{\circledR}$ 886F Biocide Acute Inhalation Toxicity Study in Rats.

37. RH (Rohm and Haas) (1975) Report No. 75RC-1001. RH886T, RH-35,375 and RH-00,345: Three Month Subchronic Oral Safety Evaluation Study in Rats.

38. RH (Rohm and Haas) (1982) Rohm and Haas Report No. 81R-162. Kathon 886 NAR: Three-Month Rat Drinking Water Study and One Generation Reproduction Study.

39. RH (Rohm and Haas) (1975) Rohm and Haas Report No. 75RC-1002. RH-886T, RH-35,375 and RH-00,345 Three Month Subchronic Oral Safety Evaluation Study in Beagle Dogs.

40. CL (Covance Laboratories) (1998) Study No.: 1154/58, "Acticide 14: 13 Week Oral (Dietary Administration) Toxicity Study in the Dog" (Sponsor: Thor Chemie GmbH), 02-98.

41. HE (Hazleton Europe) (1994) Report no: 1127-1154-002
"Acticide 14: 90 Day Dermal Sub chronic Toxicity Study to the Rat" (Sponsor: Thor Chemicals (UK) Limited), 13-0694.

42. RH (Rohm and Haas) (1982) Report No. 80R-119. Kathon 886 MW 90-Day Percutaneous Toxicity Study in Rabbits.

43. RH (Rohm and Haas) (1984) Report No. 82R-245. Kathon 886 MMPA Process: Thirteen-Week Inhalation Toxicity Study in Rats.

44. RH (Rohm and Haas) (1999) Report No. 84R-188A. Kathon 886 MW $1.5 \%$ Biocide - Skin Irritation Study in Rabbits.

45. PE (Pharmakon Europe) (1994) Report No. 53093, "Test to Evaluate Acute Primary Cutaneous Irritation and Corrosivity, in the Rabbit of Acticide 14", Sponsor: Thor Chemicals (UK) Limited, 28.03.94.

46. RH (Rohm and Haas) (1975) Report No. 74RC-1005, The Evaluation of Experiment Algaecide RH 886T as an Irritant to the Rabbit Eye.

47. RH (Rohm and Haas) (1999) Report No. 77R-060A. Kathon ${ }^{\circledR}$ CG 1.5\% Preservative Acute Toxicity/ Irritation Studies in Rats and Rabbits.

48. Smith, C. and Alexander, B. (2004) In vitro assessment of the ocular irritancy potential of isothiazolinone-based preservatives using the BCOP assay (abstract). Toxicology, 194, 263-264.

49. Gautheron, P., Dukic, M., Alix, D. and Sina, J.F. (1992) Bovine corneal opacity and permeabiliy test: an in vitro assay of ocular irritancy. Fundam. Appl. Toxicol., 18, 442-449.

50. RH (Rohm and Haas) (1993) Report No. 91RC-047. Kathon ${ }^{\circledR}$ $886 \mathrm{~F}$ Evaluation of the Upper Airway Irritation Potential (RD50).

51. RH (Rohm and Haas) (2000) Rohm and Haas Report No. 00RC-148A. Murine Local Lymph Node Assay with Chloromethylisothiazolinone/Methylisothiazolinone.

52. RH (Rohm and Haas) (2000) Rohm and Haas Report No. 00RC-148B. Murine Local Lymph Node Assay to Evaluate Chloromethylisothiazolinone/Methylisothiazolinone.

53. Warbrick, E.V., Dearman, R.J., Basketter, D.A. and Kimber, I. (1999) Influence of application vehicle on skin sensitization to methylchloroisothiazolinone/methylisothiazolinone: an analysis using the local lymph node assay. Contact Dermatitis, 41, 325-329.

54. Basketter, D.A., Gilmour, N.J., Wright, Z.M., Walters, T., Boman, A. and Liden, C. (2003) Biocides: Characterization of the allergenic hazard of Methylisothiazolinone. J. Toxicol. Cutaneous Ocular Toxicol., 22, 187-199.

55. Cardin, C.W., Weaver, J.E. and Bailey, P.T. (1986) Doseresponse assessments of Kathon biocide. (II). Threshold prophetic patch testing. Contact Dermatitis, 15, 10-16.

56. Weaver, J.E., Cardin, C.W. and Maibach, H.I. (1985) Doseresponse assessments of Kathon biocide (I). Diagnostic use and diagnostic threshold patch testing with sensitized humans. Contact Dermatitis, 12, 141-145.

57. RIVM (The National Institute for Public Health and the Environment) (2008) Allergens in Consumer Products. RIVM Report 320025001/2008. Available from: www.vwa.nl/txm$\mathrm{pub} / \mathrm{files} / \mathrm{p}$ _file_id $=31183 /$.

58. RH (Rohm and Haas) (1998) Rohm and Haas Report No. 96R-189. Kathon ${ }^{\mathrm{TM}}$ 886F Biocide: Two-Generation Reproductive Toxicity Study in Rats. 
59. RH (Rohm and Haas) (1980) Report No. 80RC-81. Kathon ${ }^{\mathrm{TM}}$ 886 Teratology Study in Rats.

60. CL (Covance Laboratories) (1998) Study No.: 1154-067, Report No: 1413-1154-067 "Two generation Oral (Gavage) Reproduction Toxicity Study in the Rat (One Litter Per Generation)" (Sponsor: Thor Chemie GmbH), 13-11-98.

61. HE (Hazleton Europe) (1994) Report no: 1178-1154-003 "ACTICIDE 14 - Oral (Gavage) Teratogenicity Study in the Rat" (Sponsor: Thor Chemicals (UK) Limited), 26-05-94.

62. JRF (Jai Research Foundation) (2002) Valvada - 396 108, Dist. Valsad, Gujarat, India Study No.: 3494, "Prenatal Development Toxicity Study of ACTICIDE 14 in Rabbits" (Sponsor: Thor GmbH), May 152002.

63. RH (Rohm and Haas) (1992) Rohm and Haas Report No. 91R-074. Kathon Biocide: Oral (Gavage) Developmental Toxicity Study in Rabbits.

64. RH (Rohm and Haas) (1976) Report No. 76RC-1001. Mutagenicity Evaluation of Kathon ${ }^{\mathrm{TM}} 886$ (All Magnesium).

65. RH (Rohm and Haas) (1981) Report No. 81R-96. Kathon ${ }^{\text {TM }}$ 886 MW: Microbial Mutagen Test.

66. RH (Rohm and Haas) (1981) Report No. 81R-97. Kathon ${ }^{\text {TM }}$ 886 NAR: Microbial Mutagen Test.

67. CCR (1992) Project No. 269201, "Salmonella typhimurium, Reverse Mutation Assay with Acticide 14", Sponsor: Thor Chemie GmbH, 31.01.92.

68. HE (Hazleton Europe) (1994) UK Study no: 1154/10R "Study to Determine the Ability of Acticide 14 to Induce Mutation in Five Histidine-Requiring Strains of Salmonella Typhimurium" (Sponsor: Thor Chemicals (UK) Ltd), 29-0694.

69. RH (Rohm and Haas) (1982) Report No. 82RC-1019. Microbial Mutagenicity Study on Kathon WT.

70. RH (Rohm and Haas) (1981) Report No. 81RC-153. Kathon ${ }^{\mathrm{TM}}$ 886 NAR: Mouse Lymphoma Forward Mutation Assay.

71. HE (Hazleton Europe) (1994) UK Study no: 1154/15 "Study to Determine the Ability of Acticide 14 to Induce Mutations at the Thymidine Kinase (tk) Locus in Mouse Lymphoma L5178Y Cells using a Fluctuation Assay" (Sponsor: Thor Chemicals (UK) Ltd), 30-06-94.

72. Scribner, H.E., McCarthy, K.L., Moss, J.N., Hayes, A.W., Smith, J.M., Cifone, M.A., Probst, G.S. and Valencia, R. (1983) The genetic toxicology of Kathon biocide, a mixture of 5-chloro-2-methyl-4-isothiazolin-3-one and 2-methyl-4isothiazolin-3-one. Mutat. Res., 118, 129-152.

73. RH (Rohm and Haas) (1990) Report No. 90RC-168. Test for Chemical Induction of Unscheduled DNA Synthesis in Rat Primary Hepatocyte Cultures by Autoradiography.

74. RH (Rohm and Haas) (1982) Report No. 82RN-1008. In Vitro Chromosomal Aberration with Kathon ${ }^{\mathrm{TM}} \mathrm{CG}$.

75. RH (Rohm and Haas) (1973) Report No. 73RC-1006. Cytogenetics Studies Compound RH 886 T.

76. RH (Rohm and Haas) (1982) Report No. 81R-181. Kathon ${ }^{\mathrm{TM}}$ 886 NAR Cytogenetic Study in Mice.

77. RH (Rohm and Haas) (1991) Report No. 90RC-169. Kathon ${ }^{\mathrm{TM}}$ 886 MW Acute Test for Chemical Induction of Chromosome Aberration in Mouse Bone Marrow Cells In Vivo.

78. RH (Rohm and Haas) (1992) Report No. 92RC-0054. Kathon $^{\text {TM }} 886$ MW Acute Test for Chemical Induction of Chromosome Aberration in Mouse Bone Marrow Cells In
Vivo.

79. RH (Rohm and Haas) (1983) Report No. 83RN-1009. Micronucleus Test Kathon ${ }^{\mathrm{TM}} 886$.

80. CL (Covance Laboratories) (1997) Marshall R., Study No.: 1154/63, Report No.: 1154/63-1052, "Acticide 14: Induction of Micronuclei in the Bone Marrow of Treated Mice" (Sponsor: Thor Chemicals (UK) Limited), 13-03-97.

81. HE (Hazleton Europe) (1994) McEnaney S., Study no: 1154/ 23 "Study to Evaluate the Potential of ACTICIDE 14 to Induce Micronuclei in the Polychromatic Erythrocytes of CD-1 Mice" (Sponsor: Thor Chemicals (UK) Ltd), 29-0694.

82. RH (Rohm and Haas) (1997) Report No. 97RC-055. Kathon ${ }^{\mathrm{TM}}$ 886F: Measurement of Unscheduled DNA Synthesis in Rat Liver Using an In Vivo/In Vitro procedure.

83. HE (Hazleton Europe) (1994) Ward P.J., Study no: 1154/24 "Study to Evaluate the Potential of ACTICIDE 14 to Induce Unscheduled DNA Synthesis in Rat Liver Using an In Vivo/ In Vitro Procedure" (Sponsor: Thor Chemicals (UK) Ltd), 30-06-94.

84. RH (Rohm and Haas) (1982) Report No. 82RC-094. Drosophila Sex-Linked Recessive Lethal Test on Kathon ${ }^{\mathrm{TM}}$ Biocide.

85. RH (Rohm and Haas) (1994) Rohm and Haas Report No. 90R-149. Kathon ${ }^{\mathrm{TM}}$ Biocide: 24-Month Drinking Water Chronic/Oncogenic Study in Rats.

86. RH (Rohm and Haas) (1983) Report No. 81R-288. Kathon CG: 30-Month Dermal Carcinogenesis Study in Male Mice.

87. RH (Rohm and Haas) (1982) Rohm and Haas Report No. 82RN-1028. Clinical Safety Evaluation of Kathon CG Phototoxicity Test.

88. Krzeminski, S.F., Brackett, C.K. and Fisher, J.D. (1975) Fate of microbicidal 3-isothiazolone compounds in the environment: modes and rates of dissipation. J. Agric. Food Chem., 23, 1060-1068.

89. deBethizy, J.D., Longacre, S.L., Steigerwalt, R.B., Deckert, F.W., Moss, J.N., Hayes, A.W., Smith, J.M. and Scribner, H.E. (1986) Absorption and disposition of 14C-labelled Kathon biocide, a mixture of 5-chloro-2-methyl-4-isothiazolin-3-one and 2-methyl-4-isothiazolin-3-one, following intravenous or dermal administration to male Sprague-Dawley rats. Food. Chem. Toxicol., 24, 43-49.

90. RH (Rohm and Haas) (1987) Report No. 86R-041. Kathon Biocide: Dermal/Oral Absorption Study in Male Rats.

91. RH (Rohm and Haas) (1987) Report No. 86R-232. Kathon Biocide: Comparison of ${ }^{14} \mathrm{C}$-Metabolite Profiles Following Oral and Dermal Dosing in Male Rats.

92. RH (Rohm and Haas) (1987) Report No. 86R-156. 14CKathon biocide: In vitro Dermal Absorption Study in Male Rat Skin.

93. MFDS (Ministry of Food and Drug Safety) (2017) Risk Assessment of Cosmetic. Available from: http://www.nifds.go.kr/ brd $/ \mathrm{m} \_15 /$ down.do?brd_id=167\&seq=10872\&data_tp $=$ A\&file_ seq $=1 /$.

94. Api, A.M., Basketter, D.A., Cadby, P.A., Cano, M.-F., Ellis, G., Gerberick, F., Griem, P., McNamee, P.M., Ryan, C.A. and Safford, R. (2008) Dermal sensitization quantitative risk assessment (QRA) for fragance ingredients. Regul. Toxicol. Pharmacol., 52, 3-23. 
95. RH (Rohm and Haas) (1990) Rohm and Haas Report No. 90RC-0017. A Double-Blind Study to Determine the Topical Contact Sensitization Potential of Three (3) Test Products.

96. Bremmer, H.J., Prud'homme de Lodder, L.C.H. and van
Engelen, J.G.M. (2006) General Fact Sheet - Limiting Conditions and Reliability, Ventilation, Room Size, Body Surface Area. Updated version for ConsExpo 4. RIVM report 320104002. 